\title{
VULNERABILITY OF MOUNTAIN COMMUNITIES TO CLIMATE CHANGE AND ADAPTATION STRATEGIES
}

\author{
Sarina Lama (MSc) ${ }^{1}$ and Bhupendra Devkota $(\mathrm{PhD})^{2}$
}

\begin{abstract}
Climate Change, one of the most important global environmental challenges facing humanity, has implications on food production, natural eco-systems, fresh water supply and health in Nepal. It is contributing mostly to the rise in air temperature leading to rapid melting of glaciers and increment of glacier lakes. Exploitation of natural resources associated with growing population has led to increasing pollution, declining water quality, land degradation, etc. Extreme climate events including flooding, heavy rainfall, droughts, heat wave and cold stream etc. are also the consequences of climate change in Nepal.

Moreover, Nepal is largely dependent on climate-sensitive sectors, such as rain-fed agriculture; its fragile mountain ecosystems and dramatic topography make the country prone to flooding. Due to such events, agricultural productivity is declining with increasing problem of food security in mountainous regions. In recent years, the signs of such changes are being observed and may become more prominent over next couple of decades. Many rural communities are struggling through different adaptation measures as an attempt to reduce the risk of climate change vulnerability.
\end{abstract}

\section{INTRODUCTION}

\section{CLIMATE CHANGE}

Global climate change has attracted much scientific and public attention in recent years, as a result of fears that human's economic activities are leading to an uncontrolled increase in Greenhouse Gas (GHG) emission and concentration in the Earth's atmosphere leading to a global rise in the Earth's temperature due to the radioactive properties of these gases. Global warming is expected to continue, with increase projected to be in the range of 1.4 to $5.8^{\circ} \mathrm{C}$ by 2100 in comparison to 1990 (IPCC 2003). There is increasing observational evidence that regional changes in climate have contributed to various changes in physical and biological systems in many parts of the world (IPCC 2003). These include the shrinkage of glaciers, changes in rainfall frequency and intensity, shifts in the growing season, early flowering of trees and emergence of insects, and shifts in the distribution ranges of plants and animals in response to changes in climatic conditions.

In context of Nepal, the global emission of greenhouse gases is negligible at per capita $\mathrm{CO}_{2}$ emission of 0.13 tonnes. But, Nepal still faces the consequences of global warming because of the geographical and climatic conditions, high dependence on natural resources and lack of resources to cope with the changing climate. The average temperature in Nepal is rising by 0.5 degrees Celsius per decade. However, such minimal change in air temperature can also lead to rapid melting of glaciers and Glacier Lakes (Dhakal, 2003). WWF Nepal Program (2005) study indicated that the Khumbu Glacier, a popular climbing route to the summit of Mt Everest, has retreated over 5kms.

The Himalayas in Nepal are geologically young and fragile and are vulnerable to even insignificant changes in the climatic system. However, in both developing and developed 
countries, the impact of climate change can be much greater for indigenous communities living in the more remote and ecologically fragile zones and relying directly on their immediate environments for subsistence and livelihood (UNFCCC, 2004).

Agricultural productivity can be affected by climate change in two ways: first, directly, due to changes in temperature, precipitation and/or $\mathrm{CO}_{2}$ levels and second, indirectly, through changes in soil, distribution and frequency of infestation by pests, insects, diseases or weeds.

\section{VULNERABILITY AND ADAPTATION CONTEXT IN NEPAL}

Due to late Monsoon and decrease in rainfall, farmers of Abukhaireni VDC in Tanahun district of Nepal were forced to slash and burn the nearby forest and cultivate in the land to cope up with the potential food shortages as they depended only on the rain-fed land (Regmi, 2005).

The Tsho Rolpa risk-reduction project in Nepal is an example of adaptation measures being implemented to address the creeping threat of glacial lake outburst flooding as a result of rising temperatures. This is one of the most significant examples of collaborative anticipatory planning by the government, donors, and experts in Glacial Lake Outburst Flood (GLOF) mitigation.

Successful adaptation reduces vulnerability to an extent that depends greatly on adaptive capacity: the ability of an affected system, region, or community to cope with the impacts and risks of climate change. Enhancement of adaptive capacity can reduce vulnerability and promote sustainable development across many dimensions (IPCC 2003).

\section{OBJECTIVES OF THE STUDY}

The objective of this research was to assess the vulnerability of indigenous mountain communities to climate change as well as to understand the adaptation strategies taken to mitigate climate-induced change on agriculture.

\section{METHODOLOGY}

\section{THE STUDY AREA}

The study area lies in the Eastern Development Region of Nepal in Solukhumbu district and within the Buffer Zone of the Sagarmatha National Park. Situated between latitudes $27^{\circ}$ $42^{\prime} 42.87^{\prime \prime}$ to $27^{\circ} 47^{\prime} 03^{\prime \prime} \mathrm{N}$ and longitudes $86^{\circ} 41^{\prime} 44.66^{\prime \prime}$ to $86^{\circ} 44^{\prime} 46.61^{\prime \prime} \mathrm{E}$, the study area is a part of Chaurikharka VDC. It covers five major settlements: namely, Jorsalle and Benkar (Ward no.1), Phakding (Ward no. 4), Chhermading (Ward no. 9) and Ghat (Ward No. 5) of Chaurikharka VDC. These settlements lie within the major trekking route of the Everest region.

\section{DATA COLLECTION}

Primary data from the study site were collected through structured interview, interview with key informants, and field observation. To ensure well-distributed representation, the selection of samples from the study area was done by a simple random sampling and on the basis of their economic categories: namely, rich, middle class and poor via wealth ranking assessment. Stratified random sampling was applied to select the household in the study villages. PRA method was applied to gather information on perception and 
awareness of climate change, vulnerability induced by climate change and adaptation measures of local mountain communities to minimize such impacts. Focused Group Discussion (FGD) was applied to understand the perceptions, attitudes and practices. Socio-Economic Vulnerability Assessment of each settlement was also calculated. In this study, six factors i.e. number of household, occupation, literacy status; assets, food sufficiency and public awareness to natural disaster were used as indicators for socioeconomic vulnerability assessment of each settlement. The total score of each village indicated the Vulnerability Indices (VI) which were then classified into three categories using "Three Categorized Ranking Method" (TCR) assigning scores of 1 to 3, 1 being the least vulnerable (Shrestha et al., 2003 in Shrestha, 2005). Socio-economic vulnerability of a settlement was calculated by combining these six $\mathrm{VI}$ and Ranking of each $\mathrm{VI}$ are as given below.

1. Higher household number in a settlement is associated with higher vulnerability.

2. People with diversified occupation are considered less vulnerable and people involved only in agriculture are considered highly vulnerable.

3. Lower level of literacy is associated with higher vulnerability.

4. People having higher property investment are considered more vulnerable.

5. Higher food deficiency is associated with higher vulnerability.

6. Lower level of awareness to natural disaster and climate change and its adaptation and mitigation options are associated with higher vulnerability.

(Source: WWF Nepal 2008)

Secondary data were collected from previous works and also the hazard maps, natural disaster profiling and analysis, land-use maps, meteorological data and topographical maps were reviewed.

\section{RESULTS AND DISCUSSION}

\section{SOCIO-DEMOGRAPHY}

The study area was found to be dominated by Sherpa (74\%) with scattered population of Rai (12\%), Magar (9\%) and Chhetri (5\%). The proportion of male and female respondent was $62 \%$ and $38 \%$, respectively, with the family size ranging from 2 to 4 , while Benkar had the highest members per household, i.e. 8. Among the studied villages, highest literacy (86\%) was found in Jorsalle, whereas Ghat had the lowest literacy (75\%).

\section{LIVELIHOOD}

More than $74 \%$ of respondents were found to have owned some form of agricultural land which were categorized into kitchen garden, upland bari and lowland bari, while the average landholding was found to be highest in Chermading (18.5 ropanies) followed by Phakding with 14.11 ropanies and Ghat with 10.69 ropanies.

Agriculture was the major occupational choice in Ghat and Chermmading with $37 \%$ of the respondents depending on it for their livelihood. The major agricultural crops grown were potato, leafy vegetables, wheat, cabbage, buckwheat, carrot, beans (white). Regarding the agricultural production sufficiency, $56 \%$ had enough food production for 9-12 months, and the rest were suffering from food deficiency. Nearly $69 \%$ of the households were found 
to cultivate crops like potatoes, leafy vegetables, cabbage, cauliflower, carrots, radish and beans for the purpose of selling.

Among the respondents, $27 \%$ stated an increment in agricultural productivity due to better rainfall timing, better farming through crop rotation, new seeds and use of organic fertilizers and training interventions. Meanwhile, the decline in agricultural produce was mainly due to pest infestation, old seeds, loss of soil nutrients, decreasing man power to work on the fields and increasing dependency on tourism.

Livestock rearing was another common income source. More than $76 \%$ of the respondents owned livestock such as cow, ox, wild boar, whereas zopke, yak, and horse, used for transport, brought twice the income compared to the human porter.

\section{RAINFALL AND TEMPERATURE}

The mean annual rainfall of about $2100 \mathrm{~mm}$ and mean monsoon rainfall of about $1750 \mathrm{~mm}$ were measured at Chaurikharka Station, estimating the year 1971 with the highest annual rainfall $(2934.7 \mathrm{~mm})$ as well as monsoon season becoming the most devastating season. As observed in the recent years, the devastations with the frequent stream flows included the washing away of the bridges near Tengboche Monastry in 2007, Thado Koshi Khola and Phakding in 2008.

Studies on temperature trends in Nepal have identified increasing trend in annual mean and annual maximum temperature in high altitude more than that of at lower altitude (Shrestha et al., 1999; Baidya et al., 2008). It clearly shows amplification of global warming in high elevation compared to low land. In addition, one of the principal concerns expressed by local respondents was the increasing danger and difficulty now experienced in carrying out traditional subsistence activities (collecting dry leaves) from the forest for manure due to the high intensity of rainfall.

Nepal's agriculture is very much dependent on the rainfall, and any significant change in air temperature can result in change in climatic conditions, like rainfall and weather conditions, resulting in shift in agriculture pattern.

\section{CLIMATE CHANGE IMPACT}

\section{Agriculture}

Potatoes harvesting was found shifted in Ghat (from Mid March to Mid January) and Phakding (from Mid March to Mid December), while leafy vegetables were shifted by 15 days in July, August and September, respectively. Though the agriculture yield has been improved in the study area, respondents stated a shift in growing time of vegetables.

Similarly, the change in flowering and fruiting patterns were also noticed in recent years. Some farmers of these settlements were happy with their potato and peach harvests as well as with increased sweetness of fruits. On the contrary, it was miserable for others, who had not only decreased size of potatoes, but also the potato seedling were smaller due to seed decaying and extreme rainfall. Additionally, decreased apple harvest was found to be due to reduced fruiting, early growing, dying and drying of apple plants, which had brought into a huge loss to the economy of the farmers. The problem was also due to the loss of agricultural produces by insect pests, like black flies, red flies, white flies, khumle with wings, and caterpillars, which were unknown to them few years back. 
The occurrence of new species of trees i.e. Uttis (Alnus Nepalenses), vegetables as pumpkin and fruits including watermelon were also observed at Phakding and this is yet to be decided whether it is due to climate change or varieties improved for high altitudes. Similarly, farmers at Ghat stated the successful harvest of ginger for the first time.

\section{Awareness}

All respondents of Jorsalle, $86 \%$ of Benkar and only $50 \%$ of Chermmading, Ghat and Phakding were aware of climate change phenomenon. Similarly, the knowledge of GLOF was also high in Ghat, Benkar, and Phakding, but $57 \%$ of the respondents at Jorsalle and $17 \%$ at Chermmading did not know about such phenomenon.

\section{Socio-Economic Vulnerability}

With the estimation of six factors i.e. number of household, occupation, literacy status, assets, food sufficiency and public awareness to natural disaster, the socio-economic vulnerability was assessed which identified Ghat village as the most vulnerable among five settlements, because of its weak adaptive capacity including highest (75\%) illiteracy, almost $100 \%$ of village respondents had agricultural land ownership, indicating high dependency on agriculture to sustain their livelihood.(Table 1).

Table 1. Socio-economic vulnerability assessment of the five settlements

\begin{tabular}{l|c|c|c|c|c|c|c|c}
\hline SETTLEMENTS & VI 1 & VI 2 & VI 3 & VI 4 & VI 5 & VI 6 & VI COMBINED & VULNERABILITY \\
\hline JORSALLE & 2 & 1 & 1 & 1 & 1 & 1 & 1.17 & $\mathrm{~L}$ \\
BENKAR & 2 & 2 & 3 & 1 & 2 & 3 & 2.17 & $\mathrm{M}$ \\
PHAKDING & 3 & 1 & 2 & 3 & 1 & 2 & 2.00 & $\mathrm{M}$ \\
CHERMMADING & 1 & 2 & 2 & 3 & 1 & 2 & 1.83 & $\mathrm{~L}$ \\
\hline GHAT & 2 & 3 & 3 & 3 & 2 & 2 & 2.50 & $\mathrm{H}$ \\
\hline
\end{tabular}

VI 1 - No. Of HHs, VI 2- Occupation, VI 3- Education, VI 4-Property Value, VI 5- Food Sufficiency, VI 6Awareness;

VULNERABILITY: $L=$ Low, $M=$ Medium, $\mathrm{H}=$ High

Similarly, according to ICIMOD (2007), the hazard assessment maps and classification of the Imja and Dudh Koshi valleys identifies the village of Ghat, Chutawa, Chhermading, Phakding and Benkar in 'Moderate Hazard' category, where there is the possibility of overtopping by the GLOF. In addition, the damage will in all likelihood lead to a chain reaction on the upper terraces in Ghat village.

The landslide hazard zonation map of Chaurikharka VDC prepared by WWF Nepal (2008) reveals that $49 \%$ of the villages lie in high hazard zone while $51 \%$ in the moderate hazard zone. The villages in high hazard zone include Jorsalle, Benkar and Phakding while the village of Chermading and Ghat was observed to be in moderate hazard zone.

During the 1985 Dig Tsho GLOF both houses and cultivated land of Ghat, Chermading, Phakding and Benkar were overtopped (ICIMOD 2007) while the respondents at Ghat (88\%) and Chermading $(67 \%)$ state the maximum loss of property i.e. land, house and livestock. While it is predicted that the severity of impact of Imja Tsho GLOF will be even greater than the Dig Tsho GLOF due to the very fast retreating rate of Imja Glacier at 74meters per year for the past decade (ICIMOD 2007). 
Similarly, with more than $74 \%$ of the respondents of Chermading, Phakding and Ghat with the highest average landholding, the impending natural disaster could result in property loss or physical capital, one of the key assets for adaptation to climate change. Meanwhile, considering the high socio-economic vulnerability of Ghat and moderate vulnerability of Benkar and Phakding, limits the ability of these communities to adapt to any disasters as a result of changing climatic condition.

\section{Adaptation}

Adoption of different practices by the respondent farmers in the major settlements was observed to cope with impacts of climate change. The planning of their agriculture was mostly based on weather calendar and particularly precipitation as well as adopting agroforestry to adapt to the reduction of forest resources for fodder and firewood.

In order to tackle change in cropping, harvesting, heavy rainfall or snowfall, respondent farmers were found adopting indigenous strategies. Some of such strategies included covering vegetables with bamboo nets (chitra), cultivating before rainy season and after snowfall, digging deep to protect from snowfall, dry leaves spread over crops (millet, carrot and cabbage), support sticks to prevent crops from falling down due to heavy rainfall. The wide spread use of indigenous plant material such as 'titepati' to combat pests that normally attacked food crops, was also found among small scale farmers which had also been used as manure mixing with dry leaves and ash.

In addition, the religious belief and faith was observed to be prominent in the region. Moreover, they were also found adopting a mixture of modern practices to protect the agricultural field. The protection of the agri-land from river overflow or in case of extreme floods was done by planting Pine and Juniper trees. Stone dykes were also constructed for fixing soil-surface nutrients, which otherwise would be washed away by runoff.

\section{CONCLUSION AND RECOMMENDATIONS}

Climate change, one of global inequity and an observed warming trend over the last few decades, is already having discernible and generally adverse impacts on the key resources. Potential intensification of monsoons combined with enhancement of GLOF risks also contribute to enhanced risk of flooding and landslides which can have serious impact on mountain agriculture and rural livelihoods. Based on socio-economic vulnerability, the village of Ghat was identified as a 'High Vulnerable Catagory' amongst the settlements because of their weak adaptive capacity to cope with the potential climate change impacts.

Subsistence production, predominantly agriculture has traditionally been the main livelihood strategy for most of the indigenous Sherpa communities. Though agriculture has its increasing yield, noticeable shifts in growing and harvesting of major crops were identified. The change in flowering and fruiting patterns was also noticed. In addition, the emergence of new species of trees i.e. Uttis (Alnus Nepalenses), vegetables like pumpkin and fruit including watermelon at Phakding might be the consequences of climate change.

To mitigate the challenges of climate change at the local/community level, risk reduction will be the entry point. Vulnerability analysis could be the key while building resilience to future climate change and climatic variability. The importance of and difficulties in building trust of communities, and using intermediaries such as NGOs for interventions can help minimize the impact of climate change on agriculture in the region. Mainstreaming 
adaptation into development activities will be essential, but requires time and patience, additional funding, knowledge and technology.

\section{ACKNOWLEDGEMENT}

The authors would like to acknowledge the financial support provided by New ERA (P) Ltd. to conduct this study.

\section{REFERENCES}

Baidya, S.K., Shrestha, M.L. and Sheikh, M.M., 2008. Trends in daily extremes of temperature and precipitation in Nepal. Journal of Hydrology and Meteorology, vol. 5(1).

Dhakal, S. 2003: One World South Asia, Kathmandu Nepal.

ICIMOD, 2007. Impacts of Climate Change on Himalayan Glaciers and Glacier Lakes.

IPCC, 2003. Climate Change 2001: Impacts, Adaptation and Vulnerability, GRID-Arendal.

Regmi, B.R., 2005. Time for action on Climate Change, "Nepal up in Smoke?" CC Risk \& Vulnerability in Nepal, LI-BIRD.

Shrestha, A.B., Wake, C.P. Mayewski, P.A. and Dibb J.E., 1999. 'Maximum temperature Trends in the Himalaya and its Vicinity: An analysis Based on temperature Records for the Period 1971-94. Journal of Climate, 12: 2775-2787.

UNFCCC, 2004: The First Ten Years. Climate Change Secretariat, Bonn, Germany

WWF Nepal, 2008: Landslide Hazard Zonation Mapping and Vulnerability Assessment along the trekking route from Ghat to Manjo in Solukhumbu District, Sagarmatha National Park and Buffer Zone.

WWF Nepal, 2005: An Overview of Glaciers, Glacier Retreat, and Subsequent Impacts in Nepal, India and China. 